\title{
Electricity Generation from Hydro, Wind, Solar and the Environment
}

\author{
Olumide A. Towoju ${ }^{a^{*}}$, Oluwatoyin A. Oladele ${ }^{b}$ \\ ${ }^{a}$ Mechanical Engineering, Lead City University, Ibadan, Nigeria. \\ ${ }^{\text {b }}$ Operations Department, Pacific Energy Company Limited, Olorunshogo, Nigeria. \\ *Corresponding author Email: olumidetowo@yahoo.com
}

\section{H I G H L I G H T S}

- Electricity generation pose an impact on the environment.

- The use of fossils for electricity generation contributes to GHG emissions.

- Reducing GHG emissions requires a shift to electricity generation from renewables.

- Climate change can affect the efficiency of renewable electricity generation.

- Renewable electricity generated synthetic fuels can be used during harsh conditions.

\section{A R T I C L E IN F O}

Handling editor: Muhsin J. Jweeg

Keywords:

Climate change

Greenhouse gas

Hydropower

Solar energy

Wind energy

\begin{abstract}
A B S T R A C T
Human actions such as electricity generation are contributory causes of climate change. In a quest to reduce the emission of greenhouse gases associated with electricity generation from fossil fuels, the world is turning to renewables. Renewable sources, however, also do have an impact on the environment. Likewise, renewable electricity generation is also dependent on the climate. Hydro, Wind, and Solar are the popular renewable energy sources for the generation of electricity. This work reviews the impact of these renewables in electricity generation on the environment. It also considers the effect of climate change on its use. The construction of renewable electricity generating plants leads to habitat disruptions and can also cause fatalities. Climate change weighs an enormous impact on the performance of renewable electricity generating plants. The recent blackout experienced in Texas as a result of the cold weather is a good example. The end of extreme weather conditions is not yet, and the need to start preparing to prevent a blackout re-occurrence. A possible solution for sustainable renewable electricity generation in extreme weather conditions lies in synthetic fuel availability.
\end{abstract}

\section{Introduction}

Climate change is real. The transformation of the usual conditions of temperature, precipitation, wind, etc., is glaring. Human actions are contributory causes of climate change. Global warming is a direct consequence of the combustion of carbonaceous substances for the release of energy. Fossil fuels are principally carbonaceous substances. The average temperature rise over pre-industrial levels is fast approaching 10C [1-3]. The percentage contribution of electricity and heat generation processes to greenhouse gases emission is about twenty-five [1,4]. Agricultural practices, transportation, and industrial processes complete the mix of greenhouse gas contributors. The electricity and heat generation sector is the main contributor to greenhouse gas emissions [4]. Its reliance on fossil fuels is now shifting to renewable energy sources. Renewable energy is increasingly becoming the choice of many nations' governments for the generation of electricity. More than twothirds of new installations for electricity generation are renewable energy-based [5]. Renewable energy is referred to as emission-free sources [3,6], although not all renewable sources are greenhouse gas emission-free when combusted, and an example is biomasses [5,7]. The combustion of fossil fuels is a major contributor to global warming. Hitherto, electricity generation relies heavily on coal because of its low cost and huge deposits. The impact of its contribution to greenhouse gas emissions, however, led to the push for a shift to gas, another fossil fuel. Greenhouse gas emissions from the combustion of coal for electricity generation in the United States was put at about 40\% of the total in 2018 [5]. Natural gas utilization for the electricity generation results in reduced greenhouse gas emissions [1,3], but not to levels that will not impact the environment. Electricity generation from non-renewables forms over Seventy percent of the total [5], and this come with the attendant greenhouse gas emissions. Renewables must come into play to replace fossil energy to keep average temperature increase below the $20 \mathrm{C}$ mark $[5,8]$. Renewable energy sourced generated electricity will grow to half of the lot by 2050 based on projections [5-6]. Geothermal, Hydropower, Ocean-Power, Solar, Wind, etc., are popular renewable sources used for 
electricity generation [3,5]. While the technology for electricity generation from Hydro sources can be said to be in a state of maturity [5,9], the same is not of the others. They are still in the development phase. Recent advances in the study of meteorology, power electronics, and energy storage have led to the increased use of wind and solar energy for electricity generation [5,10-11]. Renewable energy sources are the future resource for electricity generation to stem the negative impact of power generation on the environment. Electricity generation from renewable sources, however, can/or be impacted by climate change.

Therefore, this study seeks to consider renewable energy sourced generated electricity impact on, and the effect of climate change on it, considering the recent happenings in Texas, USA. The following section describes the scope of this work. Section 2 reviews literature regarding the environmental and climatic impact of electricity generation from hydro, wind and solar. And section 3 is a summary of studies regarding climate change impacts on electricity generation from renewables like hydro, wind, and solar. The paper closes with some concluding remarks of a possible solution under discussion.

\section{Environmental impact of renewable electricity generation}

The common renewable energy sources for electricity generation are hydro, wind, and solar. The shift towards these energy resources is to ensure that average temperature increase over the pre-industrial era is kept below 20C [5,8]. Hydroelectricity generation is reliable and stable, and with its superb return on investment, it is always an investment choice. Electricity generation from wind is cost effective, and when it is onshore installations it qualifies as the most cost effective means of electricity generation [5]. A good alternative of solving the problem of global warming according to studies is Solar generated electricity, it is clean and efficient [12]. These three sources and a summary of their impact on the environment will be considered in this section.

\subsection{Hydropower}

Dams built for electricity generation can assist in erosion control [13-14]. Dams act as a collector for water and prevent environmental degradation arising from flooding. Hydroelectric power offers the benefit of a green electricity source [5,15]. However, there lies an uncertainty on the level of greenhouse gas $(\mathrm{CO} 2)$ emitted from the hydro reservoirs due to biomass decompositions [16]. Hydro dams also do negatively impact the environment. It causes disruptions and damage to the ecosystem services and functions [5,9,16,17-18]; natural stream flow and sediments flow patterns are distorted, aquatic life is affected, and water temperature is disrupted. The blockage/disruption to the natural river and sediment flow affects the natural course of aquatic life. These disruptions come with an attendant depopulation $[16,19]$.

The temperature of stagnant water is always different from that of a flowing one. Thus, causing temperature disruptions when water flows out from a dam. Hydropower dams can also be a reason for peoples' relocation and land-use change because of the large expanse of land required for construction $[5,9,20]$. These impacts take a toll on the environment and a heavy one for that matter. The negative environmental impact of hydroelectric power generation can contribute to climate change if not properly managed. The disruptions to the ecosystem can destroy biodiversity and lead to the death of organisms. Their decomposition produces methane, a more potent greenhouse gas [17-18]. Thus, the reason why some scholars think hydroelectricity also contributes to climate change [19].

The construction of new hydroelectric dams should be done with the provision of fish ladders to assist fish migration and regular opening of the dam to allow for water flow downstream. This will lead to a reduction of its impact on the environment.

\subsection{Wind energy}

Wind energy is one of the renewable energy sources receiving rapt attention from researchers and governments of nations to mitigate the effects of electricity generation contributions to climate change. Wind-generated electricity, like the other renewables, is green [5]. It does not emit greenhouse gases [21], and hence, does minimal harm to the climate; studies have shown that wind turbines can impact regional climatic conditions [22]. Its water use is negligible, making it a non-water polluting and dependent technology, unlike other electricity-generating means [8,23]. However, it can negatively impact the environment [24] through land use and habitat loss. Wind-generated electricity has the lowest impact on habitats of the other energy sources. It, however, requires a large land area for its construction [20,25].

The land use can change the dynamics of the habitat if not well planned. Wind turbines are sources of noise pollution; this can be mechanical or aerodynamic. While the mechanical noise is now largely contained, the aerodynamic noise caused by the rotation of the turbine rotor blades generates noise [23] that can be very irritating and disturbing to nearby occupants. The construction of wind farms can also endanger the habitat of birds $[23,26]$. Collision of birds with the turbine rotor is a likely occurrence at wind farms. The collision can be fatal, and even without a bird's death or injury, an impairment/interference is made against their movement [22]. Because of the heights of wind turbines, visibility becomes a challenge at wind farm sites [22-23,27], and the movement of its blades is a cause of flickering shadows. Offshore wind farms, like onshore, do disrupt marine and plant habitats, and their decommissioning can lead to the emission of toxins which can affect aquatic life [21]. Offshore wind turbines can cause an artificial reef that can affect marine biodiversity [22].

Mitigating the negative impacts of wind-generated electricity can be achieved through conscious design and location of the turbines. This will lead to a reduction in birds' fatality, flickering shadows, and visibility challenges. 


\subsection{Solar energy}

Solar energy-generated electricity is adjudged green. It is the third in the rankings of renewable energy sourced electricity. It does not emit greenhouse gases during its operation [12,28-29] and does not directly harm to the climate. However, the construction of solar energy farms can contribute to climate change. The clearing of forests for solar panel installation contributes to climate change [5,30-31]. The subsequent decomposition of felled plants results in the release of stored carbon compounds. Also, environmental degradation, soil erosion can set in due to cleared land spans [29]. Like wind turbines, solar panels for electricity generation require a large land area for their installation. The land-use does have an impact on the environment. But unlike the wind turbine, noise is not generated during the operation of solar generators. The requirements for large land use cause disruptions in habitat set-ups and affect biodiversity [29,32]. To mitigate some of the negative impacts of deforestation on the environment, floating photovoltaic panel technology is being adopted [32].

Solar farms can also impact the bird mortality rates by colliding with the panels or contact with solar flux [33-34]. The emission of hazardous materials associated with the manufacture of solar energy components is of great concern [35]. The emission of poisonous materials can harm the environment if not properly managed. The hazardous nature of the solar panels as they reach their end of life and become wastes is of more concern [36]. A realization of this threat is pushing governments of nations to devise proper management policies for the waste panels through recycling [36]. Visual pollution is another negative impact of solar farms on the environment. Installations near highways cause visual disturbance to drivers due to sunlight reflection, and the near building installations impair people's vision [37-38]. To mitigate against the negative impacts, rooftop installations are now a common practice [39-40]. Rooftop installations reduce the demand for land and helps to preserve biodiversity. It also helps in the reduction of visual pollution and disturbance. The floating type installations of Solar panels also leads to a reduction in some of the negative environmental impacts like land requirement. The impact of using different energy resources in the generation of electricity on the environment is depicted in Table 1.

\section{Climate change impact on renewable electricity generation}

The combustion of carbonaceous substances and the decomposition of organic matter results in the emission of greenhouse gases. Significant changes are made to the environment and ultimately to the climate. Land cultivation for plants also contributes to climate change if not properly managed [41]. It is indisputable that changes have been made to the climate pattern. These changes have effects that are either positive and negative on energy generation from renewable sources $[8,42]$. An example of a negative impact was the blackout recorded in Texas in February 2021 due to the cold winter [43]. Renewable electricity is dependent on climate variables. The remaining part of this section will be devoted to the impacts of climate change on the three (3) popular electricity generation renewable energy sources and proffer solutions to mitigating the negative impact.

\subsection{Hydropower generation}

Climate change has led to an increment of average temperatures $[1-3,5,8]$. The relatively warmer temperature is a recipe for increased rainfall [5]. Air temperature and precipitation are direct consequences of climate change and affect streamflow. Hydropower generation flourishes with the availability of water to fill up its dams. However, while climate change can boost electricity generation from hydro-dams in some regions, it can hamper others. Rainfall pattern change can cause some areas to experience increased rainfalls, while some will experience drought. A rainfall pattern change is a threat to hydropower generation [5]. It is essential to note that increased rainfall may not be beneficial for hydropower generation in all instances. Flooding and landslide can result from increased rainfall leading to increased sediments in dams and the attendant negative impact on the hydropower plants [8]

Global warming is also the cause of glaciers retreat with its attendant impact on water discharge [44-46]. Disruption of water discharge is a challenge to existing hydro-dams and likewise to newer ones. Increased temperature does not only affect precipitation; it also has a direct impact on surface water evaporation [8]. It takes a toll on the reservoir water quantity and power generation. Also, increased mechanical stress of the plant components results from increased average air temperature.

Climate change is a threat to the continued generation of electricity from hydro-dams, however, this threat can be properly managed. Areas with increased rainfalls can harness the rains by constructing dams which will in addition to electricity generation, will assist in checking erosion and help save the environment.

\subsection{Electricity generation from Wind}

Wind speeds have increased over the years thanks to climate change [47]. The performance of wind turbines is majorly dependent on wind speed [48]. Hence, climate change can affect the performance of wind turbines. Climate change causes shifts in geographical distribution and variability of wind [48-49] and can affect existing wind turbines and newer installations. Global warming affects soil stability, results in ice melting, leads to sea-level rise, and threatens both onshore and offshore construction of wind turbines [8,50]. There is no gainsaying that increased average air temperature is a consequence of climate change. The rotation speed of the wind turbine blades is a function of wind energy (momentum). Wind energy affects the power output from the turbines [8,49]. Temperature values affect air density, a key parameter of wind energy, and hence climate change can impact wind turbine performance through average temperature increase. 
Table 1: Electricity Generation from Different Resources

\begin{tabular}{ccccc}
\hline Energy Resource & $\begin{array}{c}\text { Clea } \\
\text { n }\end{array}$ & Noise pollution & Affect Biodiversity & Animal mortality \\
\hline Fossil & & $\mathrm{X}$ & $\mathrm{X}$ & \\
Nuclear & $\mathrm{X}$ & $\mathrm{X}$ & $\mathrm{X}$ & $\mathrm{X}$ \\
Hydro & $\mathrm{X}$ & & $\mathrm{X}$ & $\mathrm{X}$ \\
Wind & $\mathrm{X}$ & $\mathrm{X}$ & $\mathrm{X}$ & $\mathrm{X}$ \\
Solar & $\mathrm{X}$ & & & \\
Biomass & $\mathrm{X}$ & & & \\
\hline
\end{tabular}

While global warming is always attributable to climate change occasioned by greenhouse gas emissions, it is also good to note that extreme cold temperature is also a consequence of climate change. Extreme cold can cause turbine blade icing and affect the performance and durability of the turbine [49]. A recent case is that of Texas in February 2021 that resulted in blackouts. The cold period led to the icing of the turbine blades and subsequently prevented the turbines from operating. However, there are many arguments as to what caused the total power outage. An incontestable fact is that the cold weather put the wind turbines out of operation, a reason for increased pressure on other generators and the subsequent collapse of the system.

While electricity generation from wind turbines during freezing temperatures might be impossible due to turbine blades icing, a concept that can be researched on is the installation of heaters on the blades. This can be powered with other energy sources like synthetic fuels and employed when situations warrant it.

\subsection{Electricity generation from Solar}

The efficiency of solar cells is negatively affected by an increase in global temperature [51-52]. Global warming results in increased average temperature, thus negatively impacting the electricity generation capacity of solar cells. Also, a warmer climate may lead to lesser solar radiation [5] and hence, a decrease in the efficiency of the solar power plant [52]. Increased precipitation is also a characteristic impact of climate change. It can lead to reduced solar radiation and reduced electricity output from solar plants [8]. There is also a tendency for an increased level of cloud formation with its attendant impact on the performance of solar power plants due to warmer temperatures.

Cold weather is a consequence of climate change. It leads to icing and increased snowfalls that result in reduced output of solar power plants [52]. Increased wind speeds can have a twin impact on the performance of solar power plants. While increased wind speeds aid the cooling of the modules and the attendant boost in efficiency and output, it can also increase debris that causes material damage [53].

Climate change is real and its attendant effect can only but managed. Construction of floating solar panels can help mitigate the impact of increased temperature on the performance of the panels.

\subsection{Synthetic fuels}

Extreme weather has impacts on the common renewable energy sources and this can lead to blackouts during this period. Also, generation from these renewable energy sources are peaked during some period of the day, and supply is in excess of demand. This excess energy can be stored by utilizing it in the generation of synthetic fuel, a Carbon-neutral fuel [2]. The synthetic fuel can be utilized to generate electricity in extreme cold weather when other forms of renewables fail. Antifreeze are usually additives to liquid fuels, and this in synthetic fuels will make it resistant to freezing during harsh weather. An advantage of utilizing synthetic fuel as an energy storage and electricity generation source is that it is a high energy carrier just like other liquid fuels, and can fit in the existing liquid fuel storage systems [2].

\section{Conclusions}

While all hands are on deck in the continuous reduction of the human contribution to climate change by reducing greenhouse gas emissions, we must continue to find means of navigating through this menace. An obvious scenario that must continue to put scholars on their toes is the recent power blackout encountered in Texas, the United States of America, in the winter of 2021. The world has not yet seen the end of extreme weather conditions. This study has concentrated on renewable electricity generation and climate change. The reduction of the emission of greenhouse gases requires the transition from fos sil energy generated electricity to renewables.

Man has learned to live with the impact of global warming on electricity generation from renewables. However, the recent cold weather in Texas has shown that our preparedness to adapt to climate change's effect on the deployment of renewable electricity is still at a low. How can electricity demand be met with renewables during cold weather with the background knowledge that hydropower, wind turbines, and solar plants are adversely affected during this period?

It is on record that the gas power turbines of the Texas electricity generation companies were also down during the winter blackouts due to the blockage of gas pipes. Therefore, the use of the plants during cold weather may not be a good option. It is, however, understood that liquid fuels with antifreeze additives show good resistance to freezing during extra cold weather situations. Liquid fuels can come to play during this period, but they cannot be fossil fuel derivatives to ensure a greener world. Renewable electricity generated synthetic fuels are carbon-neutral and can help to salvage the situation. It can be produced during peak periods of renewably generated electricity and stored for use when the need arises. 
Studies on the commercial production of synthetic fuels must be encouraged. Synthetic fuels hold the key to sustainable electricity generation in the face of climate change. Electricity generation can be shored up with synthetic fuels when climate change dawns on the renewable electricity generation sources. Thus, help to prevent the attendant electricity outages.

\section{Acknowledgment}

The author acknowledge Lead City University for providing an enabling environment to carry out this study.

\section{Author contribution}

The first author conceptualized and prepared the manuscript. The second author assisted in proof reading the manuscript.

\section{Funding}

This research received no specific grant from any funding agency in the public, commercial, or not-for-profit sectors.

\section{Data availability statement}

The data that support the findings of this study are available on request from the corresponding author.

\section{Conflicts of interest}

The authors declare that there is no conflict of interest.

\section{References}

[1] O. A. Towoju and F. A. Ishola, A Case for the internal combustion engine powered vehicle, Energy Rep., 6 (2020) 315 321. https://doi.org/10.1016/j.egyr.2019.11.082

[2] O. A. Towoju, Fuels for automobiles; the sustainable future, Int. J. Energy Res.. 7 (2021) 8-13. https://doi.org/10.9734/JENRR/2021/v7i330191

[3] O. A. Towoju, Carbon footprint reduction with the adoption of the electricity-powered vehicles, Int. Energy J. (IEJ), 21 (2021) 101-106.

[4] IPCC. Summary for policymakers. In: O. Edenhofer, R. Pichs-Madruga, Y. Sokona, E. Farahani, S. Kadner, K. Seyboth A. Adler, I. Baum, S. Brunner, P. Eickemeier, B. Kriemann, J. Savolainen, S. Schlömer, C. von Stechow, T. Zwickel, J.C. Minx; editors. Climate change 2014: mitigation of climate change. Contribution of working group III to the fifth assessment report of the intergovernmental panel on climate change. Cambridge, United Kingdom and New York, NY, USA: Cambridge University Press; 2014.

[5] O. A. Towoju and F. A. Ishola, Pros and cons of electricity generation from different available energy sources, Int. Rev. Mech. Eng., 14 (2020) 374-380. https://doi.org/10.15866/ireme.v14i6.19104.

[6] M. A. Islam, M. Hasanuzzaman, N. Rahim, A. Nahar, and M. Hosenuzzaman. Global renewable energy-based electricity generation and smart grid system for energy security, Sci. World J., 197136 (2014). https://doi.org/10.1155/2014/197136

[7] A. Freiberg, J. Scharfe, V. C. Murta, and A. Seidler. The use of biomass for electricity generation: a scoping review of health effects on humans in residential and occupational settings, Int J. Environ Res Public Health. 15 (2018) 1-27.

[8] K. Solaun and E. Cerda, Climate change impact on renewable energy generation: a review of quantitative projections, Renew. Sust. Energ. Rev., 116 (2019) 1-16. https://doi.org/10.1016/j.rser.2019.109415

[9] F. C. Jônatas da Mata, A. Z. Mesquita, and R. O. Neto, Comparison of the performance, advantages and disadvantages of nuclear power generation compared to other clean sources of electricity, International Nuclear Atlantic Conference INAC, 2017.

[10] J. B. Olson, J. S. Kenyon, I. Djalalova, L Bianco, D. D. Turner, Y. Pichugina, A. Choukulkar, M. D. Toy, J. M. Brown, W. M. Angevine, E. Akish, Jian-W. Bao, P. Jimenez, B. Kosovic, K. A. Lundquist, C. Draxl,J. K. Lundquist, J. McCaa, K. McCaffrey, K. Lantz, C. Long, J. Wilczak, R. Banta, M. Marquis, S. Redfern, L. K. Berg, W. Shaw, and J. Cline. Improving wind energy forecasting through numerical weather prediction model development, Bull. Amer. Meteor. Soc. 100 (2019) 2201-2220. https://doi.org/10.1175/BAMS-D-18-0040.1

[11] R. Dash and S. C. Swain, Effective power quality improvement using dynamic activate compensation system with renewable grid interfaced sources, Ain Shams Eng. J., 9 (2018) 2897-2905.

[12] C. Ayoo, Towards energy security for the twenty-first century, Intech Open, 1-26, 2020.

[13] D. J. Soeder, M. S. Scyller, J. Borglum, 7 - Energy economics, The Fossil Fuel Revolution: Shale Gas and Tight Oil, 213247, 2019. https://doi.org/10.1016/B978-0-12-815397-0.00008-2. 
[14] S. Yuan, Z. Li, P. Li, G. Xu, H. Gao, L. Xiao, F. Wang, and T. Wang. Influence of check dams on flood and erosion dynamic processes of a small watershed in the loess plateau, Water, 11 (2019) 1-16. https://doi.org/10.3390/w11040834

[15] Utah State University, Strategies to reduce environmental damage from dams, Science Daily. 2016. [Online], Available: Www.sciencedaily.com/releases/2016/09/160909112300.htm.

[16] Energy Sage, Environmental impacts of hydropower, 2019. Accessed on 05/04/2021, [Online], Available: https://www.energysage.com/about-clean-energy/hydropower/environmental-impacts-hydropower/

[17] E. Ezcurra, E. Barrious, P. Ezcurra, A. Ezcurra, S. Vanderplank, O. VIdal, L. Villanueva-Almanza, and O. AburtoOropeza. A natural experiment reveals the impact of hydroelectric dams on the estuaries of tropical rivers, Sci. Adv., 5 (2019) 1-9.

[18] D. M. Rosenberg, P. McCully, and C. M. Pringle, Global-scale environmental effects of hydrological alterations: Introduction, Bioscience, 50 (2000) 746-751.

[19] M. Mussa, H. Teka, and H. Ayicho, Environmental impacts of hydropower and alternative mitigation measures, current investigations in agriculture and current research, 2 (2018). http//: doi:10.32474/CIACR.2018.02.000133

[20] J. Yardley, Chinese dam projects criticized for their human costs, New York Times, November 19, 2007.

[21] M. Faizal1, R. K. Chelvan, and A. Amirah, Energy economic and environmental impact of wind power in Malaysia, Int. J. Adv. Sci. Res. Manag., 2 (2017) 81-87.

[22] K. Dai, A. Bergot, C. Liang, W. Xiang, and Z. Huang. Environmental issues associated with wind energy - A review, Renewable Energy, 75 (2015) 911-921. http://dx.doi.org/10.1016/j.renene.2014.10.074.

[23] R. Saidur, N. A. Rahim, M. R. Islam, and K. H. Solangi. Environmental impact of wind energy, Renew. Sust. Energ. Rev., 15 (2011) 2423-2430. https://doi.org/10.1016/j.rser.2011.02.024

[24] K. Abeliotis, and D. Pactiti, Assessment of the environmental impacts of a wind farm in central greece during its life cycle, Int. J. Renew. Energy Res., 4 (2014) 580-585.

[25] POST. Carbon footprint of electricity generation, Post note by Parliamentary Office of Science and Technology, 268 (2006) 1-4.

[26] P. Magoha, Footprints in the wind? ; environmental impacts of wind power development, Fuel and Energy Abstracts, 44 (2003) 161.

[27] L. Jacob. Visual impact assessment of offshore wind farms and prior experience, Applied Energy, 86 (2009) $380-7$.

[28] V. M. Fthenakis, H. C. Kim, and E. Alsema, Emissions from photovoltaic life cycles emissions from photovoltaic life cycles, Environ. Sci. Technol. 42 (2008) 2168-2174.

[29] G. D. Pimentel Da Silva and D. A. C. Branco, Is floating photovoltaic better than conventional photovoltaic? Assessing environmental impacts, Impact Assess. Proj. Appraisal. 36 (2018) 390-400, 2018.

[30] D. Turney and V. Fthenakis, Environmental impacts from the installation and operation of large-scale solar power plants, Renew. Sust. Energy Rev. 15 (2011) 3261-3270. https://doi.org/10.1016/j.rser.2011.04.023

[31] A. J. Swart and P. E. Hertzog, Varying percentages of full uniform shading of a PV module in a controlled environment yields linear power reduction, J. Energy South. Africa, 27 (2016) 28-38.

[32] A. Gasparatos, C. N. H. Doll, M. Esteban, A. Ahmed, and T. A. Olang. Renewable energy and biodiversity: implications for transitioning to a Green Economy, Renew Sustain Energy Rev. 70 (2017) 161-184. https://doi.org/10.1080/14615517.2018.1477498

[33] M. Grippo, J. W. Hayse, and B. L. O’Connor, Solar energy development and aquatic ecosystems in the Southwestern United States: potential impacts, mitigation, and research needs, Environ Assess. 55 (2015) 244-256.

[34] L. J. Jr. Walston, K. E. Rollins, K. E. LaGory, K. P. Smith, and S. A. Meyers. A preliminary assessment of avian mortality at utility-scale solar energy facilities in the United States, Renew Energy. 92 (2016) 405-414.

[35] M. Tawalbeh, A. A. Othman, F., Kafiah, E. Abdelsalam, F. Almomani, and M. Alkasrawi. Environmental impacts of solar photovoltaic systems: A critical review of recent progress and future outlook, Science of The Total Environment. 759 (2021). https://doi.org/10.1016/j.scitotenv.2020.143528

[36] S. Chowdhury, K. S. Rahman, T. Chowdhury, N. Nuthammachot, K. Techato, M. Akhtaruzzaman, S. K. Tiong, K. Sopian, and N. Amin. An overview of solar photovoltaic panels' end-of-life material recycling, Energy Strategy Rev., 27 (2020) 1 -11. https://doi.org/10.1016/j.esr.2019.100431

[37] T. Guerin, A case study identifying and mitigating the environmental and community impacts from construction of a utility-scale solar photovoltaic power plant in eastern Australia, Sol. Energy, 146 (2017) 94-104. 
[38] A. Dhar, A. Natth, P. D. Jennings, and M. G. El-Din. Perspectives on environmental impacts and a land reclamation strategy for solar and wind energy systems, Sci. Total Environ., 718 (2020) 134602. https://doi.org/10.1016/j.scitotenv.2019.134602

[39] T. Salameh, H. Assad, M. Tawalbeh, C. Ghenai, A. Merabet, and H. F. Oztop. Analysis of cooling load on commercial building in UAE climate using building integrated photovoltaic façade system, Sol. Energy, 199 (2020) 617-629.

[40] J. Bazán,J. Rieradevall, X. Gabarrell, I. Vazquez-Rowe. Low-carbon electricity production through the implementation of photovoltaic panels in rooftops in urban environments: a case study for three cities in Peru, Sci. Total Environ. (2018) $1448-1462$.

[41] O. A. Towoju, and F. A. Ishola, Feasibility studies of the conversion of agricultural and metal wastes into use as a brake pad, a numerical approach, J. Adv. Res. Fluid Mech. Therm. Sci., 75 (2020) 58-67. https://doi.org/10.37934/arfmts.75.1.5867.

[42] J. Cronin, G. Anandarajah, and O. Dessens, Climate change impacts on the energy system: a review of trends and gaps, Clim Change, 151 (2019) 79-93.

[43] A. Chang, Why The Cold Weather Caused Huge Texas Blackouts - A Visual Explainer, February, 2021, Accessed on 24/03/2021, [Online], Available: https://www.theguardian.com/us-news/2021/feb/20/texas-power-grid-explainer-winterweather.

[44] P. Mukheibir, Potential consequences of projected climate change impacts on hydroelectricity generation, Climate Change, 121 (2013) 67-78. https://doi.org/ 10.1007/s10584-013-0890-5.

[45] H. Zekollari, M. Huss, and D. Farinotti, Modelling the future evolution of glaciers in the European Alps under the EUROCORDEX RCM ensemble, Cryosphere, 13 (2019) 1125-1146.

[46] L. Laurent, J. Buonicristiani, B. Pohl, H. Zekollari, D. Farinotti, M. Huss, J. Mugnier, and J. Perguad. The impact of climate change and glacier mass loss on the hydrology in the Mont-Blanc massif, Sci. Rep, 10 (2020) 1-11. https://doi.org/10.1038/s41598-020-67379-7

[47] C. Harvey, The Worlds Winds Are Speeding Up. Scientific American, Accessed on 19/04/2021, Nov 2019 [Online], Available: https://www.scientificamerican.com/article/the-worlds-winds-are-speeding-up/ .

[48] D. Carvalho, A. Rocha, M. Gomez-Gesteira, C. S. Santos. Potential Impacts of Climate Change on European Wind Energy Resource under The CMIP5 Future Climate Projections, Renew Energy, 101 (2017) 29-40. https://doi.org/10.1016/j. renene.2016.08.036.

[49] S. C. Pryor and R. J. Barthelmie, Assessing the vulnerability of wind energy to climate change and extreme events, Clim Change, 121 (2013) 79-91. https://doi.org/ 10.1007/s10584-013-0889-y.

[50] A. Mroz, J. Holnicki-Szulc, and T. Karna, Mitigation of ice loading on off-shore wind turbines: feasibility study of a semi-active solution, Comput Struct, 86 (2008) 217-26. https://doi.org/10.1016/j.compstruc.2007.01.039

[51] A. Razak, Y.M Irwan, W.Z. Leow, M Irwanto, I. Safwati, M. Zhafarina . Investigation of the effect temperature on photovoltaic (pv) panel output performance, Int. J. Adv. Sci. Eng. Inf. Technol., 6 (2016) 682-688. https://doi.org/10.18517/ijaseit.6.5.938.

[52] J. C. Perez, A. Gonzalez, J. P. Diaz, F. J. Exposito, J. Felipe. Climate change impact on future photovoltaic resource potential in an orographically complex archipelago, the Canary Islands, Renew Energy, 133 (2019) 749-59. https://doi.org/10.1016/j. renene.2018.10.077.

[53] A. Patt, S. Pfenninger, and J. Lilliestam, J. Vulnerability of solar energy infrastructure and output to climate change, Clim Change, 121 (2013) 93-102. https://doi.org/ 10.1007/s10584-013-0887-0. 